\title{
Feminism Representation in Kartini Movie 2017 (Semiotic Analysis Jhon Fiske)
}

\author{
Sonia Eka Lidyawati, Amin Aminudin \\ Universitas Budi Luhur, Indonesia \\ soniaekalidya@gmail.com, amin.aminudin@budiluhur.ac.id
}

\begin{abstract}
Movie is a means to deliver messages for wider audience. One of it is R.A Kartini movie, a biopic directed by Hanung Bramantyo. This movie tells about Kartini's struggle to prosper women, especially Indonesian women. The title of this study was chosen because feminism became an always interesting thing to discuss and Kartini's thoughts and ideas became a bridge for young scholars who adore her thoughts. The formulation of the problem and the main purpose of this study is to understand how feminism in Kartini movie (2017) is represented. This is a qualitative study by using Jhon Fiske semiotic theory where the theory divide those sign into three codes: reality, representation, and ideology. Paradigm used on this study is a critic paradigm where critical paradigm could criticize and transform deviate sosial connection. The results of this study, Kartini represents feminism into three codes which is reality levels where the cultural reality represented in the movie is the reality of Kartini's life in the mean at this reality level which picturing the life of Javanese women in Kartini's era. Kartini is indeed a figure of feminism who fought inequality in her life, but she never forgot where she came from and the manners that she had to uphold in order to maintain the dignity of her family. On the representasion levels, Kartini movie (2017) represents feminism using dialogue, music, lighting, and angle of camera. On the ideological levels, Kartini showed her resistance into patriarchy with her feminist ideas and thoughts regarding cultural rules where she believe it doesn't treat women equally, therefore women don't have their freedom. The result from this analysis about representation in Kartini movie is that Kartini's feminism can be concluded as liberal feminism and the reason why Kartini can be concluded as a liberal thinker because Kartini promoted education as a means to help women to get out from poverty, ignorance and inequality.
\end{abstract}

Keyword : Feminism, Kartini, Film, Semiotika Jhon Fiske. 